\title{
Relasi Remaja - Orang Tua dan Ketika Teknologi Masuk di Dalamnya
}

\section{The Adolescent - Parent Relationships and When Technology Gets Involved}

\author{
Novi Qonitatin', Faturochman 2, Avin Fadilla Helmi³, Badrun Kartowagiran ${ }^{4}$ \\ 1,2,3 Fakultas Psikologi, Universitas Gadjah Mada, ${ }^{4}$ Program Studi Penelitian dan Evaluasi \\ Pendidikan, Universitas Negeri Yogyakarta, ${ }^{1}$ Fakultas Psikologi, Universitas Diponegoro
}

\section{Submit 21 Maret 2019 Diterima 31 Mei 2019 Terbit 22 Juni 2020}

\begin{abstract}
The adolescent-parent relationship has unique characteristics because of changes that occur as a result of the transition from childhood to adulthood in adolescence. The inclusion of technology in family life influences relationship between adolescents and their parents. This article intends to conduct a conceptual mapping of adolescent-parent relationship and technology. Studies on the relationship can be categorized into several findings, such as: (1) definition of adolescent-parent relationship; (2) aspects of relationship associated with the important components that build a relationship; (3) dimensions of relationship that show its characteristics; and (4) structure of relationship that shows its pattern. Literature review found that there are some major determinants that affect relationship, i.e., social perception in the intrapersonal domain, communication in the interpersonal domain, and a variety of subgroups in a group domain. There were positive and negative consequences due to the use of technology in adolescent-parent relationships.
\end{abstract}

Keywords: adolescent-parent relationships; aspects; definition; dimensional; structure; technology

\begin{abstract}
Abstrak. Relasi remaja-orang tua memiliki karakteristik unik karena perubahan yang terjadi sebagai akibat dari transisi masa kanak-kanak ke dewasa pada remaja. Masuknya teknologi dalam kehidupan keluarga turut berpengaruh terhadap relasi antara remaja dan orang tua mereka. Tulisan ini bertujuan untuk melakukan pemetaan konseptual relasi remaja - orang tua dan pengaruh teknologi dalam relasi tersebut. Hasil kajian terurai dalam berbagai konsep yang dikerucutkan menjadi beberapa temuan, seperti: (1) definisi relasi remaja-orang tua, (2) aspek-aspek relasi terkait dengan bagian-bagian yang membentuk relasi, (3) dimensi relasi yang menunjukkan karakteristik relasi; dan (4) struktur relasi yang menunjukkan pola relasi. Penelaahan riset menemukan bahwa ada beberapa determinan utama yang memengaruhi relasi, seperti persepsi sosial dalam domain intrapersonal, komunikasi dalam domain antarpribadi, dan variasi sub kelompok dalam domain kelompok. Selain itu, terdapat dampak positif dan negatif karena penggunaan teknologi dalam relasi remaja-orang tua.
\end{abstract}

Kata kunci: aspek; definisi; dimensi; relasi remaja - orang tua; struktur; teknologi

\footnotetext{
${ }^{1}$ Korespondensi mengenai artikel ini dapat melalui: ${ }^{1}$ qonitatin@gmail.com, ${ }^{2}$ faturpsi@ugm.ac.id,

3avin_psi@ugm.ac.id, ${ }^{4}$ kartowagiran@uny.ac.id
} 


\section{Pengantar}

Relasi merupakan konsep umum yang banyak dibicarakan dalam ilmu psikologi, seperti relasi manusia, relasi sosial, atau pun relasi interpersonal. Jenisnya beragam, antara lain relasi orang tua dengan anak, relasi pasangan, relasi antar rekan kerja, relasi pertemanan, relasi tetangga, dan lain sebagainya. Khusus pada relasi di dalam keluarga, setiap relasi di antara anggota keluarga pun memiliki karakteristik yang unik, seperti relasi ketika anak menginjak pada masa remaja. Steinberg (2016) menyatakan bahwa masa remaja adalah suatu periode ketika remaja mencari jati diri. Remaja akan mengalami berbagai perubahan yang dapat memberikan transformasi dan re-organisasi dalam relasi keluarga (Steinberg, 2016). Dalam menghadapi perubahan relasi, orang tua harus mampu mengatur relasi saling ketergantungan di dalam sistem keluarga dan jaringan sosial untuk sistem sosial di luar keluarga (Bandura, 1995).

Perubahan dalam relasi juga terdampak dari penyesuaian keluarga di era modern. Modernisasi, terutama terkait dengan kemajuan teknologi akan memberikan perubahan dalam penggunaan teknologi dalam rutinitas sehari-hari individu yang berdampak pada perubahan interaksi sosialnya (McGrath, 2012) antara lain, komunikasi online melengkapi komunikasi tatap muka (Odendaal, Malcolm, Savahl, \& September, 2006). Dapat dikatakan bahwa teknologi menjadi bagian tidak terpisahkan dalam relasi interpersonal (Walther, 2011) dan membawa pada pergeseran yang tampak dalam relasi keluarga. Keterhubungan antar anggota keluarga menjadi lebih banyak didominasi melalui teknologi (Christensen, 2009; Hertlein, 2012; Pamungkas, 2014).

Tujuan artikel ini adalah membangun konsep relasi remaja-orang tua terkait dengan teknologi berdasarkan studi literatur. Seperti diketahui bahwa perkembangan teknologi yang semakin pesat turut mewarnai relasi yang terjadi antar individu. Keunikan dan kekhasan relasi antara remaja dan orang tua, terutama dengan sentuhan generasi digital yang berbeda akan memberikan pengaruh dalam penggunaan teknologi dalam relasi mereka. Permasalahan-permasalahan sering kali muncul, seperti temuan-temuan yang memperlihatkan bahwa penggunaan teknologi dapat menjadi sumber konflik atau sumber ketegangan yang terus berlangsung bagi banyak keluarga (Blackwell, Gardiner, \& Schoenebeck, 2016; Subrahmanyam \& Šmahel, 2011). Diharapkan sumbangan pemikiran mengenai relasi remaja-orang tua yang dikaitkan dengan teknologi akan dapat digunakan untuk memahami lebih mendalam pada jenis relasi tersebut dan dapat membantu dalam mengembangkan relasi yang lebih baik.

\section{Pembahasan}

\section{Relasi Remaja - Orang Tua}

\section{Pengertian Relasi}

Pemahaman tentang relasi banyak diungkapkan dalam berbagai istilah. Relasi merupakan sebagai suatu interaksi (Antonnucci, 2001; Higgins, 1982; Kelley, 1983; Liska, 1998; Reis, Collins, \& Berscheid, 2000; Thibaut \& Kelley dalam Shaw \& Costanzo, 1985); transaksi (Calhoun \& Acocella, 1990); hubungan (Kruglanski \& Higgins, 2007; Reading, 1996); dan asosiasi (Manstead \& Hewstone, 1996).

Dari berbagai definisi para ahli, dapat disimpulkan adanya ciri-ciri relasi, sebagai berikut. Pertama, Melibatkan dua orang atau lebih. Relasi tidak dapat sendirian, akan tetapi selalu melibatkan dua orang (Berscheid \& Ammazzalorso, 2004; 


\section{QONITATIN, DKK}

Calhoun \& Acocella, 1990); dua orang atau lebih (Gillovich, Keltner, \& Nisbett, 2011; Higgins, 1982; Liska, 1998; Manstead \& Hewstone, 1996; Thibaut dan Kelley dalam Shaw \& Costanzo, 1985; Taylor, Peplau, \& Sears, 1994). Bahkan secara spesifik, relasi sosial merupakan suatu hubungan antara dua individu yang disebut dengan "dyad", tiga individu disebut dengan "triad" atau lebih yang disebut dengan "kelompok sosial” (Kruglanski \& Higgins, 2007).

Kedua, Kesalingterpengaruhan. Dalam relasi suatu perubahan perilaku pada seseorang akan menghasilkan perubahan perilaku pada orang lainnya (Berscheid \& Ammazzalorso, 2004; Reis et al., 2000). Thibaut dan Kelley pada tahun 1978 telah mendefinisikan relasi interpersonal sebagai interaksi yang muncul ketika dua orang menampilkan perilaku pada kehadiran salah seorangnya (Shaw \& Costanzo, 1985), dan bahkan pengaruh dari seseorang terhadap orang lain bersifat kuat dan sering (Kelley, 1983). Reading (1996) menyebutnya dengan serangkaian modus perilaku A kepada B, dan B kepada A. Hal ini menunjukkan ada saling pengaruh perilaku antara individu A dan B ketika menjalin relasi. Tipe perilaku yang dipengaruhi pun berbeda-beda dan banyak (Kelley, 1983), dan dapat menjadi ciri pertukaran sosial antara orang-orang (Antonnucci, 2001).

Ketiga, Dampak keterpengaruhan. Relasi interpersonal yang terjalin akan saling memengaruhi secara verbal, fisik, atau emosional (Taylor et al., 1994), atau berpengaruh pada pikiran, perasaan dan perilaku masing-masing (Manstead \& Hewstone, 1996). Calhoun \& Acocella (1990) secara khusus menyatakan bahwa relasi akan melibatkan suatu rangkaian sinyal-sinyal emosional masing-masing yang unik.
Keempat, Jangka panjang. Relasi terjalin dalam suatu pola interaksi yang memakan waktu yang lama (Calhoun \& Acocella, 1990; Gillovich et al., 2011; Kelley, 1983; Manstead \& Hewstone, 1996), dan keberlangsungannya sampai kepada pengharapan untuk berinteraksi di masa yang akan datang (Manstead \& Hewstone, 1996).

Definisi dari beberapa tokoh mengenai relasi tidak menunjukkan adanya kontradiksi yang kuat, hampir seluruh definisi menunjukkan kesamaan konseptual dalam memaknakan mengenai relasi. Simpulan dari uraian yang telah dipaparkan sebelumnya adalah bahwa relasi mencakup: (a) adanya pola interaksi, (b) terdiri dari dua orang atau lebih; (c) ada saling pengaruh, baik dalam pikiran, perasaan, dan perilaku, dan (d) berlangsung dalam waktu yang lama, bahkan di waktu yang akan datang.

\section{Relasi orang tua dan remaja}

Telaah referensi mengenai pengertian relasi remaja-orang tua memang lebih banyak membahas mengenai definisi relasi itu sendiri dibandingkan secara khusus mendefinisikan relasi remajaorang tua. Akan tetapi dapat dikatakan bahwa ketika mengkaji mengenai relasi remaja-orang tua akan berkaitan dengan jenis relasi yang secara khusus terjadi antara dua individu atau lebih yang berbeda dalam posisi atau peran, yaitu antara remaja dan orang tua (ayah dan ibu). Merujuk pada pengertian-pengertian mengenai relasi secara umum, relasi remaja - orang tua dapat didefinisikan sebagai suatu pola interaksi yang terjalin antara remaja dan orang tua dengan adanya saling pengaruh dan berlangsung dalam waktu yang lama serta memiliki keberlanjutan di masa yang akan datang. 
Remaja sering kali sulit untuk didefinsikan melalui usia kronologis, akan tetapi menurut Gouws, Kruger, dan Burger (2008) dapat dibagi menjadi tiga klasifikasi, yaitu (1) remaja awal yang berkisar antara 11 sampai 13 tahun; (2) remaja tengah yang berada pada usia 14 sampai 17 tahun; dan (3) remaja akhir yang berada pada usia 18 sampai dengan 22 tahun. Masa remaja dikenal sebagai masa peralihan atau masa transisi dari masa kanakkanak menuju dewasa (Feldman, 2009; Manstead \& Hewstone, 1996; Papalia, Olds, \& Feldman, 2007; Santrock, 2007). Masa ini juga disebut dengan masa kritis (Manstead \& Hewstone, 1996) yang ditampilkan dengan munculnya masalahmasalah perilaku dan penyesuaian yang umum terjadi pada remaja, dan mereka dituntut untuk dapat memahami dan menerima perubahan-perubahan yang terjadi pada remaja berikut penyesuaian dan penyelesaian tugas perkembangannya (Sarwono, 2008; Duvall dalam Setiono, 2011). Konflik dalam relasi pun ditemukan secara temporer meningkat ketika anak beranjak remaja (Allison, 2000; De-Goede, Branje, \& Meeus, 2008; Mcgue, Elkins, Walden, \& Iacono, 2005; Steinberg, 2016)

Dukungan penelitian telah menunjukkan bahwa ketika remaja dan orang tuanya mampu menjalin relasi yang baik akan dapat menjadi proteksi efektif dalam penyesuaian masalah-masalah yang terjadi di dalam tahap perkembangan remaja (Coatsworth, Duncan, Greenberg, \& Nix, 2010; Wang et al., 2013) serta memunculkan kelekatan emosional antara remaja dan orang tua (Bettmann \& Tucker, 2011) dan kepuasan dalam pengasuhan (Obsuth, Moretti, Holland, Braber, \& Cross, 2006). Selain itu, stabilitas relasi orang tua dengan remaja akan memengaruhi relasi remaja di masa yang akan datang, serta menekankan pentingnya relasi orang tua dan remaja dalam kesejahteraan psikologis dan kualitas relasi romantis remaja (Drake, 2013); dan kualitas yang baik dalam orientasi pada teman sebaya (Fuligni \& Eccles, 1993).

Sebaliknya, kekurangan atau keterbatasan yang diperoleh di dalam relasi dengan orang tua, dapat membawa pada kecenderungan perilaku kenakalan pada remaja dan permasalahan remaja lainnya. Seperti internalisasi masalah-masalah orang tua pada anak yang muncul dalam bentuk depresi dan kecemasan (Hughes \& Gullone, 2010; Moore, Kinghorn, \& Bandy, 2011); serta eksternalisasi masalah-masalah perilaku (Moore et al., 2011; Poduthase, 2012; Soenens, Vansteenkiste, Luyckx, \& Goossens, 2006; Stattin \& Kerr, 2000).

\section{Dimensi Relasi Orang tua-Remaja}

Relasi banyak dikaji dengan konsep yang beragam. Penguraian mengenai relasi ada yang disebutkan sebagai aspek, dimensi, karakteristik, tipe, struktur, proses, ataupun kategori. Beragamnya uraian dari relasi ini menyebabkan perlunya untuk membuat suatu kesimpulan yang tepat dalam memetakan aspek atau dimensi relasi. Aspek dan dimensi relasi remaja orang tua sebagai salah satu jenis relasi sosial, turut dapat dikembangkan berdasarkan aspek dan dimensi yang ditemukan pada relasi secara umum.

Dari berbagai referensi ditemukan bahwa aspek relasi secara umum terdiri dari social network, social support, dan sense of control (Antonnucci, 2001); support, conflict, dan power(De-Goede et al., 2008); dominance, power, dan status sebagai aspek relasi sosial (Hall, Coats, \& LeBeau, 2005); dan penekanan yang penting dalam relasi yaitu aspek dukungan sosial(Campo et al., 2009). Telaah lebih lanjut dari aspek-aspek tersebut menemukan aspek support dan power menjadi hal yang sama dari bebe- 


\section{QONITATIN, DKK}

rapa perspektif di atas. Sense of control yang dikemukakan oleh (Antonnucci, 2001) ternyata memiliki konotasi yang sama dengan power, karena ia mendefinisikannya sebagai tingkat perasaan indivi$\mathrm{du}$ untuk mengontrol suatu situasi yang memiliki makna yang sama dengan kekuatan akan kuasa mengatur situasi. Sedangkan, ketiga aspek yang dikemukakan oleh Hall et al. (2005) merupakan aspek dalam dimensi vertikal yang samasama menjelaskan mengenai adanya posisi atau kedudukan berbeda antar individu dalam suatu relasi. Hal ini sebenarnya menunjukkan makna tentang kekuasaan.

Tidak seperti aspek dukungan dan kekuasaan yang menjadi aspek utama yang ditemukan dalam kebanyakan referensi tentang relasi, aspek konflik sedikit berbeda karena tidak semua referensi yang ditemukan menyatakan bahwa aspek relasi mengandung konflik. Akan tetapi, De-Goede et al. (2008) menyatakan bahwa konflik menjadi bagian yang penting dalam relasi remaja-orang tua selain dukungan dan kekuasaan. Steinberg dan Silk (2002)telah menggambarkan tiga ranah pengasuhan yang merefleksikan aspek-aspek penting dalam relasi remajaorang tua. Tiga ranah tersebut antara lain harmony domain (misalnya dukungan), autonomy domain (misalnya keterbukaan, pemberian otonomi), dan conflict domain (misalnya kebencian, konflik). Selain itu menurut De-Goede et al. (2008), banyak teori meliputi perspektif neo-psikoanalitik, evolusioner, dan sosial-kognitif, menyatakan bahwa peningkatan otonomi dan individuasi selama remaja membawa pada suatu penurunan temporer kedekatan, peningkatan konflik, dan secara perlahan lebih menunjukkan kekuasaan yang lebih setara. Hal ini juga menunjukkan tentang adanya support, power dan conflict, yang kemudian dapat disimpulkan sebagai aspek dalam relasi remaja-orang tua.

Antonnucci (2001)menyebutkan social network sebagai salah satu aspek dari relasi. Social network yang dimaksud adalah karakteristik objektif yang menggambarkan siapa individu yang melakukan relasi interpersonal, dalam hal ini terkait dengan usia, jenis kelamin, peran relasi, lama mengenal, kedekatan tempat tinggal, frekuensi kontak, dan lain sebagainya. Aspek ini lebih banyak menyangkut mengenai karakteristik demografi dari individu yang menjalin relasi, serupa dengan status dalam aspek yang diungkapkan oleh Hall et al. (2005). Telah banyak penelitian yang mengkaji seperti usia, jenis kelamin, status sosial, sub-sub kelompok dalam keluarga seperti etnis, status keluarga, kewarganegaraan, memberikan perbedaan dalam kualitas relasi (Claes et al., 2011; Moore et al., 2011; Saxena, Srivastava, \& Naithani, 2011). Oleh karena fungsinya yang lebih banyak sebagai determinan dibandingkan sebagai bagian yang membentuk relasi, status atau social network lebih tepat bila dipandang sebagai anteseden.

Dari ranah dimensi, ada dua perspektif yang memberikan konsep yang hampir mirip. Pada tahun 1976, Wish, Deutsch, dan Kaplan menyebutkan empat dimensi dalam relasi, yaitu (1) Cooperative/Friendly vs. Competitive/Hostile, (2) Equal vs. Unequal Status, (3) Intense vs. Superficial, dan (4) Socioemotional/ Informal vs. Task-oriented/ Formal (Reis et al., 2000). Deutsch (2012) kemudian menguraikan menjadi lima dimensi relasi sosial yang sejalan dengan dimensi sebelumnya, yaitu (1) Cooperation - Competition, (2) Equality - Inequality, (3) Task-oriented vs. Social-emotional oriented, (4) Formal vs. Informal, dan (5) Degree of importance. 
Dari kedua perspektif ini sebenarnya dapat terlihat persamaan dimensi yang dimiliki. Dimensi keempat yaitu Socioemotional/Informal vs. Task-oriented/Formal pada Wish dan kawan-kawan dipecah menjadi dua dimensi yang berbeda pada definisi dari Deutsch. Penelaahan lebih lanjut menyimpulkan bahwa dimensi tingkat kepentingan dari Deutsch bisa dikaitkan dengan dimensi dari Wish dan kawan-kawan yang melihat apakah relasi tersebut bersifat dangkal atau dalam. Dimensi-dimensi inilah yang memberi karakteristik pada relasi antar individu, dimana semua dimensi ada pada suatu relasi dengan jenis yang bervariasi.

Ranah yang lain seperti tipe atau struktur bisa disejajarkan sebagai jenis relasi. Reis et al. (2000) menjelaskan bahwa tipe relasi terdiri dari relasi romantis, parental, pertemanan, rekan kerja, dan tetangga. Jenis yang lain dikemukakan oleh Clark dan Mills yang menjelaskan bahwa tipe relasi terdiri dari Exchange Relationship dan Communal Relationship (Clark \& Mills, 2012; Gillovich et al., 2011). Jenis ini hampir serupa dengan yang dikemukakan oleh Fiske pada tahun 1990 tentang struktur relasi (Fiske, 2004; Fiske dalam Manstead \& Hewstone, 1996) dengan menambahkan adanya dua jenis relasi lain, menjadi (a) Communal Sharing (serupa dengan communal relationship), (b) Authority Ranking, (c) Equality Matching, dan (d) Market Pricing (serupa dengan exchange relationship).

\section{Faktor dan Dampak Relasi Remaja-Orang Tua}

Pemetaan riset relasi remaja-orang tua ini akan melihat pada beberapa hal, yaitu (1) faktor-faktor yang berpengaruh terhadap relasi sebagai antecendent, dan (2) dampak dari relasi tersebut sebagai output atau outcome. Hal ini sejalan dengan pendapat Reis et al. (2000) yang menyatakan bahwa tujuan dari ilmu relasi adalah pemahaman tentang dinamika relasi beserta antecendens dan consequences dari relasi tersebut. Dengan demikian, dalam peta riset ini dilakukan pemetaan jalur kausal yang terlibat dalam relasi, khususnya relasi remaja-orang tua.

Dalam membahas anteseden, tampak beberapa faktor yang berpengaruh terhadap relasi yang dapat dibagi menjadi tiga ranah utama. Pada ranah intrapersonal, persepsi memainkan peran yang penting dalam relasi (Claes et al., 2011; De-Goede et al., 2008; Fuligni \& Eccles, 1993; Reis et al., 2000). Reis et al. (2000) telah mengumpulkan bukti-bukti yang secara jelas memperlihatkan bahwa manusia tidak akan merespons stimulus yang sama dengan cara yang sama pada suatu konteks relasi. Hal ini mengindikasikan bahwa pemaknaan terhadap stimulus pada individu dapat berubah dengan cepat sesuai dengan perubahan-perubahan yang terjadi dalam konteks relasi. Tampak jelas pada hasil penelitian Claes et al. (2011) yang melihat perbedaan persepsi antara remaja di Kanada, Italia dan Prancis pada perilaku parental orang tua. Ikatan emosional dipersepsikan sama oleh remaja di tiga negara tersebut, tetapi kontrol orang tua dipersepsikan dengan cara yang berbeda yang memberikan pengaruh terhadap kualitas relasi remaja dan orang tua. Fuligni dan Eccles (1993) melihat pentingnya persepsi dalam relasi seperti salah satu temuan mereka bahwa ketika remaja mempersepsikan orang tua tidak memberikan peluang untuk pengambilan kesempatan, mereka cenderung tidak meminta nasihat dari orang tua dan justru mencari teman untuk membicarakan masalah pribadi dan masa depan.

Pada ranah interpersonal, komunikasi memainkan peran yang penting dalam relasi remaja-orang tua (Kuhar, 2010; 


\section{QONITATIN, DKK}

Lingyun, 2010). Williams (2003) mempelajari bahwa komunikasi menjadi pusat dalam relasi remaja dan orang tua. Ia mengonseptualisasikan komunikasi remaja dengan orang tua sebagai proses yang dinamis dalam relasi. Bahkan Lingyun (2010) menemukan bahwa untuk mengoptimalkan relasi remaja-orang tua harus ada pemahaman mutual antara orang tua dengan anak yang perlu dikembangkan.

Pada ranah kelompok, adanya variasi sub-sub kelompok dalam keluarga juga akan memengaruhi relasi. Moore et al. (2011) menemukan bahwa kualitas relasi orang tua dan anak bervariasi pada subsub kelompok, seperti pasangan berkulit putih, hitam dan hispanik; pasangan menikah atau kohabitasi; keluarga dengan pendapatan tinggi-rendah; lelaki dan perempuan, kanak-kanak dan remaja, imigran-non imigran; dan orang tua dengan tingkat pendidikan yang berbeda. Seperti salah satu kajian yang dilakukan di Cina oleh Lingyun (2010)yang meneliti relasi remaja dengan orang tua yang melibatkan keduanya, menemukan bahwa relasi orang tua dan anak bervariasi berdasarkan jenis kelamin dan tingkat pendidikan. Status sosial keluarga juga memberikan perbedaan relasi remaja dengan orang tuanya (Saxena et al., 2011), dan asal negara memberikan perbedaan remaja dalam memersepsi relasi dengan orang tuanya (Claes et al., 2011).

Output atau outcome sebagai konsekuensi dari relasi juga memperlihatkan dampak-dampak yang signifikan bagi remaja maupun orang tua. Sebagai dampak positif, relasi berhubungan dengan self-esteem (Widiastuti \& Widjaja, 2004; Yaacob, 2006), kesejahteraan psikologis (Drake, 2013)dan emosional (Koen, 2009), kepuasan pengasuhan (Obsuth et al., 2006), efek proteksi risiko keluarga(Coatsworth et al., 2010; Wang et al., 2013), kelekatan emosional (Bettmann \& Tucker, 2011), dan kualitas relasi romantis atau sebaya (Drake, 2013; Fuligni \& Eccles, 1993).

Di sisi lain, relasi orang tua dengan anak ditemukan berhubungan dengan internalisasi masalah-masalah orang tua pada anak, seperti depresi dan kecemasan (Hughes \& Gullone, 2010; Moore et al., 2011); dan eksternalisasi masalah-masalah perilaku (Moore et al., 2011; Poduthase, 2012; Soenens et al., 2006; Stattin \& Kerr, 2000). McKinney dan Renk (2011) menyebutkan bahwa pada masa remaja ditandai dengan suatu peningkatan internalisasi dan eksternalisasi masalah-masalah dan dapat berperan dalam membentuk fondasi bagi perkembangan remaja itu sendiri di masa depan. Masa remaja merupakan masa transisi didalam perubahan relasi remaja-orang tua dan meningkatkan prevalensi dari internalisasi dan eksternalisasi masalah-masalah pada remaja (Fanti, Henrich, Brookmeyer, \& Kuperminc, 2008). Banyak penelitian yang melihat bahwa kualitas relasi remaja dan orang tua mereka berhubungan dengan masalah-masalah perilaku dan emosi.

\section{Relasi Remaja-Orang Tua dan Teknologi}

Remaja menjadi usia yang paling mudah mendapatkan imbas dari perkembangan teknologi yang ditunjukkan dengan temuan yang memperlihatkan bahwa remaja adalah pengguna paling produktif situs jaringan sosial dan menghabiskan sebagian besar hidup keseharian mereka melalui interaksi dengan media sosial (Ahn, 2011), ataupun komunikasi elektronik (Subrahmanyam \& Greenfield, 2008). Generasi remaja disebutkan sebagai generasi millennial atau digital natives, yaitu mereka yang lahir ketika teknologi telah berkembang pesat dan kehidupan mereka tidak pernah terlepas dari teknologi (Partini, 2017). 
Sebaliknya, orang tua di abad ke-21 ini juga mendapatkan tantangan untuk memanfaatkan teknologi sebagai bagian dari upaya menyesuaikan cara berelasi remaja. Orang tua pun hidup dalam tatanan teknologi yang sudah berkembang pesat, dan mau tidak mau akan melakukan adaptasi terhadap penggunaannya. Orang tua yang masuk dalam generasi digital immigrant lahir ketika teknologi belum berkembang sepesat ini sehingga penggunaan teknologi pada kehidupan sehari-hari sangat minim (Partini, 2017). Masih menurut Partini (2017), memang generasi ini tidak lahir dalam konteks teknologi yang tinggi akan tetapi mau dan mampu untuk belajar teknologi baru dengan tidak meninggalkan begitu saja tradisi-tradisi lama yang sudah lama dipegang. Pada akhirnya hal ini lah yang kemudian memungkinkan relasi antar dua generasi ini berbentuk interaksi sosial yang bergeser menjadi interaksi yang termediasi oleh media, atau dengan kata lain realitas nyata digantikan hiper-realitas maya. Hal yang menjadi tantangan kemudian adalah bagaimana orang tua dan remaja yang memiliki sentuhan generasi teknologi yang berbeda dapat saling memahami 'bicara' yang dimediasi oleh teknologi saat ini, seperti yang diutarakan oleh Prensky (2010).

\section{CMC dalam Relasi Remaja-Orang Tua}

Pemahaman relasi remaja - orang tua dengan melibatkan teknologi tidak lepas dari pemahaman akan computer-mediated communication (CMC), yang merupakan bentuk komunikasi yang terjadi melalui penggunaan teknologi. CMC muncul ketika dua atau lebih individu berinteraksi melalui perangkat elektronik (Attril, 2015). Percakapan secara online menjadi titik temu antar individu walaupun ada keterbatasan dalam jarak dan waktu (Peris et al., 2002). Sifat asynchronous menjadi ciri dari $\mathrm{CMC}$, yaitu ditandai dengan adanya interaksi real-time dalam jaringan jarak dekat maupun jauh yang dapat memudahkan pengguna dalam membuat, mengirim dan menerima pesan secara instan, yang biasanya dalam bentuk tertulis (Smith, 2003). Sifat asynchronous ini juga memungkinkan pengguna memiliki potensi untuk menghasilkan presentasi lebih optimal dikarenakan adanya waktu yang lebih banyak dalam menyampaikan pesan kepada orang lain (Fullwood, 2015), dan dapat melakukan pengeditan terhadap pesan yang akan dikirim (Walther, 2011).

Walther (2011) mengungkapkan bahwa dengan sifat tersebut akan membangun relasi yang intens dengan orang lain sehingga komunikasi hyperpersonal yang terwujud dalam CMC menjadi lebih menarik dibandingkan dengan komunikasi tatap muka, termasuk dikarenakan berbagai kemudahan yang dimiliki. Bahkan CMC dikatakan dapat mengatasi hambatan jarak yang biasanya ditemui dalam komunikasi tatap muka, serta kemudahan dalam memilih bentuk komunikasi yang paling sesuai digunakan dalam menjalin relasi (Amichai-Hamburger, 2012). CMC akan dapat mengikat koneksi antar individu sehingga tetap dapat berhubungan walaupun ada keterbatasan jarak (Amichai-Hamburger, 2012; Christensen, 2009). Bahkan beberapa penelitian lain mencatat bahwa konteks sosial dalam komunikasi yang dimediasi komputer dianggap lebih penting daripada komunikasi tatap muka (Fullwood, 2015; Walther, 2011).

Sifat dari CMC ini lah yang memberi warna baru dalam relasi remaja - orang tua ketika melibatkan teknologi di dalamnya. Tingkat keterbukaan juga menjadi lebih baik, misalnya anggota keluarga menggunakan pesan teks dibandingkan 


\section{QONITATIN, DKK}

dengan komunikasi verbal secara langsung untuk menghindari konflik atau memperkuat aturan (Pamungkas, 2014; Rudi, Walknerm, \& Dworkin, 2014).Chang dan Hsin (2016) menemukan hasil penelitian yang memperlihatkan bahwa remaja lebih menyukai menggunakan pesan singkat untuk berkomunikasi dengan orang tuanya, yang justru dapat memotivasi mereka untuk mengekspresikan perasaan. Kajian tentang penggunaan teknologi komunikasi dengan interaksi orang tua dan remaja di Indonesia juga telah dilakukan oleh Pamungkas (2014) yang menemukan alasan remaja menyukai penggunaan teknologi dalam berinteraksi dengan orang tua mereka. Alasan utama remaja adalah penggunaan teknologi dalam relasi mengurangi budaya malu bertemu orang tua karena dapat berbicara dengan orang tua tanpa harus bertatap muka, yaitu melalui online. Hal ini dapat terjadi seperti apa yang dikemukakan oleh (Hertlein, 2012), remaja dan orang tua yang berkomunikasi secara online lebih mengandalkan konten daripada yang terjadi dalam konteks relasi tatap muka, karena lebih tidak terikat pada kepatuhan norma-norma sosial dan meningkatkan partisipasi dalam perilaku tanpa adanya hambatan.

\section{Dampak Teknologi dalam Relasi Remaja- Orang Tua}

Penggunaan teknologi digital dapat menjadi sumber koordinasi dan membangun relasi dalam keluarga (Jennings \& Wartella, 2004). Hal ini sejalan dengan Padilla-Walker (2006) dan Christensen (2009) yang menemukan bagaimana teknologi terutama penggunaan ponsel dapat menghubungkan atau memediasi perasaan kedekatan ketika orang tua dan anak secara fisik terpisah. Termasuk penggunaan pesan teks atau pesan instan pada orang tua untuk dapat berkomunikasi dengan remaja (Subrahmanyam \& Greenfield, 2008). Christensen (2009) menyimpulkan adanya peran teknologi media dalam mengintegrasikan keluarga melalui cara memediasi perasaan kedekatan ketika berada di dalam jarak fisik yang jauh. Peran tersebut juga termasuk membuat keluarga lebih mudah untuk memutuskan berada dalam posisi jauh (terpencar) karena adanya kemudahan dalam komunikasi antar anggota keluarga yang dimediasi oleh teknologi. Perasaan terkoneksi ini juga muncul dalam penelitian Padilla-Walker, Coyne dan Fraser (dalam Coyne, Bushman, \& Nathanson, 2012) dengan penggunaan media melalui cara yang bervariasi.

Rudi et al. (2014) menyatakan bahwa penggunaan teknologi memberikan banyak pilihan komunikasi dibandingkan dengan komunikasi tatap muka, dengan fungsi yang menunjukkan dapat membantu untuk mempertahankan hubungan atau sebagai cara tambahan untuk tetap terhubung dan menunjukkan kasih sayang antara remaja dan orang tua. Tidak ada keraguan bahwa alat seperti telepon seluler dan pesan instan, memungkinkan anggota keluarga untuk lebih sering berhubungan satu sama lain dibandingkan dengan waktu sebelumnya, bahkan dapat lebih dekat dan tetap terhubung (Christensen, 2009; Subrahmanyam \& Šmahel, 2011).

Teknologi media dinyatakan memiliki peran penting dalam keluarga, terutama penggunaan media untuk menambah wawasan dalam masa transisi yang dialami pada relasi remaja - orang tua. Topik yang paling penting yang diperoleh dari teknologi media pada keluarga adalah monitoring parental dalam penggunaan teknologi oleh remaja, khususnya usaha mencegah efek merusak dari teknologi 
media (Coyne et al., 2012). Hal ini juga dinyatakan oleh Subrahmanyam dan Greenfield (2008) yang menemukan bahwa semakin banyak orang tua beralih ke pesan teks atau pesan instan untuk berkomunikasi dengan anak mereka yang remaja, yang bagi orang tua sangat berguna untuk mengawasi anak. Ponsel memberi sarana bagi orang tua untuk memantau dan meminta informasi tentang keberadaan, teman, aktivitas terkini dari remaja (Weisskirch, 2009). Teknologi dan perubahan norma-norma sosial yang telah terjadi sebagai dampaknya membuat orang tua lebih mudah untuk mengendalikan hampir semua aspek kehidupan anak (Cosgrove, 2016).

Di sisi lain, remaja juga memanfaatkan alat komunikasi elektronik terutama untuk memperkuat relasi yang ada (Pamungkas, 2014; Subrahmanyam \& Greenfield, 2008). Dalam konteks penggunaan teknologi, Weisskirch (2009) telah melihat hubungan timbal balik, dimana orang tua memantau dan meminta informasi tentang status remaja sebaliknya remaja juga dapat berkomunikasi dengan orang tua untuk menginformasikan aktivitas bahkan untuk meminta dukungan. Pengaruh positif dari penggunaan teknologi adalah kesempatan untuk mengembangkan dan meningkatkan relasi dengan keluarga jauh dan teman pada kehidupan keluarga (Sharaiveska, 2012).

Akan tetapi hal yang kontradiktif ditemukan dalam relasi remaja dengan penggunaan teknologi khususnya media elektronik, yaitu terjadi peningkatan relasi dengan teman sebaya tetapi mengorbankan kualitas relasi keluarga, terutama relasi remaja dengan orang tua (Liu, Yin, \& Huang, 2013; Subrahmanyam \& Greenfield, 2008). Seperti halnya temuan Rajeev dan Jobilal (2015) yang memperlihatkan hasil bahwa penggunaan ponsel pada remaja memberi dampak pada relasi, antara lain hubungan yang baik dengan teman akan tetapi kurang usaha untuk mempertahankan relasi yang baik dengan orang tua. Hal ini sebenarnya turut diperkuat dengan karakteristik remaja yang lebih dekat dengan teman (peer group) dibandingkan dengan orang tuanya (Santrock, 2007; Sarwono, 2008). Muncul kenyataan yang menemukan bahwa remaja khususnya, sering kali mengabaikan komunikasi atau chat dari orang tua mereka dibandingkan ketika berkomunikasi atau chat dengan teman (Susandijani, 2017).

Mengingat bahwa kesenjangan generasi sangat memengaruhi adopsi teknologi (Baileya \& Ngwenyama, 2010). Penggunaan teknologi dalam keluarga juga dapat memberikan ketegangan atau konflik yang menjadi sumber permasalahan yang terus berlangsung bagi banyak keluarga (Blackwell, Gardiner, \& Schoenebeck, 2016; Subrahmanyam \& Šmahel, 2011). Banyak orang tua merasa tidak tahu dan cemas tentang apa yang anak mereka lakukan secara online. Orang tua menjadi semakin sulit untuk tetap waspada terhadap yang dilakukan anak-anak mereka dengan teknologi, terutama dengan adanya bentuk komunikasi elektronik yang lebih baru seperti situs jejaring sosial sehingga membuat mereka kesulitan untuk mengendalikan atau bahkan memengaruhi kegiatan online anak-anak mereka.

Odendaal et al. (2006) telah mengumpulkan data penelitian lain yang memperlihatkan perbedaan antara orang tua dan remaja dalam kaitannya dengan teknologi tergambarkan sebagai pengalaman negatif. Mereka menemukan bahwa sebagian besar orang tua dalam penelitiannya dianggap oleh anak remajanya kurang memiliki pengetahuan tentang teknologi digital dibandingkan dirinya. Bahkan 


\section{QONITATIN, DKK}

relasi remaja dan orang tua menjadi terhambat ketika orang tua tidak antusias dengan teknologi dan gagal memahami signifikansi sosial untuk memiliki akses dalam teknologi. Hal ini menyebabkan remaja menganggap tuntutan dan pentingnya mereka untuk memiliki dan menggunakan teknologi dianggap oleh orang tua tidak berguna. Masih menurut Odendaal et al. (2006), kondisi ini dapat terjadi karena orang tua yang mungkin tertinggal dalam menguasai dan menggunakan media teknologi informasi tersebut.

McGrath (2012) menambahkan bahwa penggunaan teknologi informasi dan media ternyata memberi dampak negatif pada interaksi sosial antara individuindividu di dalam rumah tangga karena mengarah pada peningkatan isolasi sosial dan privatisasi di dalam rumah. Pengaruh negatif dari penggunaan teknologi yang sangat intens dalam keluarga justru membuat berkurangnya waktu interaksi (Moawad \& Ebrahem, 2016; Sharaiveska, 2012) dan perhatian dalam interaksi (Sharaiveska, 2012), atau perasaan koneksi yang menjadi rendah khususnya dalam perspektif remaja (Padilla-Walker, Coyne, \& Fraser, 2012). Minimnya pengetahuan dan kemampuan orang tua dalam teknologi juga membuat berkurangnya peran orang tua dalam pemberian informasi kepada remaja (Hertlein, 2012) dan pengawasan ketika remaja mengakses internet akibat adanya perasaan asing dalam penggunaan teknologi (Odendaal et al., 2006).

Sebagai akhir dari kajian relasi remaja - orang tua dan teknologi, tidak dapat dipungkiri bahwa teknologi telah menyentuh seluruh lapisan masyarakat, termasuk keluarga. Perkembangan teknologi yang semakin pesat memfasilitasi terjadinya perubahan ritme dan rutinitas sehari-hari dalam relasi keluarga (Hertlein, 2012;
Padilla-Walker et al., 2012). Temuantemuan kontradiktif dalam dampak penggunaan teknologi dalam keluarga masih perlu ditindaklanjuti dengan penelitianpenelitian yang disesuaikan dengan konteks yang lebih spesifik pada keluarga. Rekomendasi dari beberapa hasil penelitian menunjukkan perlunya kebutuhan dari orang tua untuk meningkatkan pemahaman dan penggunaan teknologi agar dapat mengakomodasi kebutuhan remaja dalam keterlibatan teknologi pada relasi remaja - orang tua, serta menghindari konsekuensi negatif yang mungkin terjadi (Moawad \& Ebrahem, 2016).

\section{Penutup}

Kesimpulan dari paparan yang telah diuraikan sebelumnya, menemukan beberapa hal yaitu (1) relasi remaja-orang tua dapat didefinisikan secara konseptual sebagai suatu pola interaksi yang terjalin antara remaja dan orang tua yang memiliki saling pengaruh serta berlangsung dalam waktu yang lama; (2) aspek-aspek relasi yang terkait dengan bagian-bagian penting yang membentuk relasi seseorang antara lain adalah support, power, dan conflict; (3) ada dimensi yang menunjukkan karakteristik dari suatu relasi yang dibangun oleh dua orang atau lebih yang terdiri dari (1) Cooperation - Competition, (2) Equality Inequality, (3) Task-oriented vs. Socialemotional oriented, (4) Formal vs. Informal, dan (5) Degree of importance; dan (4) terdapat struktur relasi yang menunjukkan pola relasi yang dipilih oleh individu yaitu Communal Sharing, Authority Ranking, Equality Matching, dan Market Pricing.

Hasil dari penelusuran riset juga menemukan beberapa faktor yang memengaruhi relasi seperti persepsi sosial dalam ranah intrapersonal, komunikasi dalam ranah interpersonal, dan variasi 
dari kelompok-kelompok dalam ranah kelompok. Ada dampak positif dan negatif sebagai konsekuensi yang dikembangkan dalam relasi remaja-orang tua. Kualitas relasi remaja dengan orang tuanya akan turut berhubungan dengan perilaku atau emosi remaja.

Penggunaan teknologi di dalam relasi remaja - orang tua telah memberikan bentuk yang berbeda dalam menjalin interaksi di dalamnya. Perbedaan generasi di dalam sentuhan teknologi sering kali menjadi sumber permasalahan, akan tetapi di sisi lain dapat memberikan manfaat sebagai media koordinasi dalam keluarga. Implikasinya, Indonesia sebagai negara yang terus berkembang dan meningkat dalam penggunaan teknologi pun tidak terlepas dalam bentuk relasi yang baru ini. Pertumbuhan pengguna internet di Indonesia setiap tahunnya adalah $10,12 \%$, dengan persentase pengguna dalam kelompok rentang usia 15-19 tahun sebesar 91\% (APJII, 2019). Perbandingan persentase antar kelompok rentang usia telah menunjukkan remaja sebagai pengguna internet tertinggi. Intensitas yang tinggi dalam penggunaan teknologi pada remaja tersebut, juga membawa dampak pada penyesuaian orang tua dalam merespon kebutuhan tersebut dengan tepat. Bukan hanya terkait dengan perubahan-perubahan yang terjadi pada remaja, tetapi juga perubahan dalam kontekstual seperti budaya yang tumbuh dan berkembang akibat kemajuan teknologi yang pesat.

Teknologi telah dinyatakan dapat memediasi perasaan kedekatan ketika keluarga secara fisik terpisah dan menjadi sarana penting untuk menjalin relasi antar individu. Oleh karena itu penting untuk mempertimbangkannya dalam konteks hubungan interpersonal. Seperti yang dikemukakan oleh Subrahmanyam dan
Greenfield (2008) dengan asumsi bahwa kita mungkin tidak pernah tahu perubahan frekuensi komunikasi tatap muka ke komunikasi yang dimediasi oleh teknologi secara absolut, akan tetapi nyata bahwa karakteristik dari komunikasi elektronik secara intrinsik telah mengubah relasi sosial kita.

\section{Daftar Pustaka}

Ahn, J. (2011). Advances in information science, the effect of social network sites on adolescents' social and academic development: Current theories and controversies. Journal of The American Society for Information Science and Technology, 62(8), 1435-1445. doi: $\underline{10.1002 / a s i .21540}$

Allison, B. N. (2000). Parent-adolescent conflict in early adolescence: Research and implications for middle school programs. Journal of Family and Consumer Sciences Education, 18(2), 1-6.

Amichai-Hamburger, Y. (2012). Reducing intergroup conflict in the digital age. In Howard Giles, C. Gallois, J. Harwood, M. Hewstone, M. Hogg, S. A. Reid, \& J. C. Turner (Eds.), Handbook of Intergroup Communication. New York: Routledge. doi: 10.4324/9780203148624.ch14

Antonnucci, T. C. (2001). Social relations: An examination of social networks, social support, and sense of control. In J. E. Birren \& K. W. Schaie (Eds.), Handbook od The Psychology of Aging. San Diego: Academic Press.

Attril, A. (2015). Cyberpsychology. New York: Oxford University Press.

APJII. (2019). Penetrasi \& profil perilaku pengguna internet Indonesia tahun 2018. In Asosiasi Penyelenggara Jasa Internet Indonesia Polling Indonesia. 


\section{QONITATIN, DKK}

Diunduh dari www.apjii.or.id

Baileya, A., \& Ngwenyama, O. (2010). Bridging the generation gap in ICT use: Interrogating identity, technology and interaction in community telecenters. Information Technology for Development, 16(1), 62-82. doi: $\underline{10.1080 / 02681100903566156}$

Bandura, A. (1995). Exercise of personal and collective efficacy in changing societies. In self-efficacy in changing society. Cambridge: Cambridge University Press.

Berscheid, E., \& Ammazzalorso, H. (2004). Emotional experience in close relationship. In M. B. Brewer \& M. Hewstone (Eds.), Emotion and motivation. Malden: Blackwell Publishers Ltd.

Bettmann, J. E., \& Tucker, A. R. (2011). Shifts in attachment relationships: A study of adolescents in Wilderness Treatment. Child Youth Care Forum, 40, 499-519. doi: 10.1007/s10566-011-9146$\underline{6}$

Blackwell, L., Gardiner, E., \& Schoenebeck, S. Y. (2016). Managing expectation: Technology tensions among parents and teens. In CSCW 2016. Proceedings of the 19th ACM Conference on Computer-Supported Cooperative Work \& Social Computing (pp. 1390-1401).

Calhoun, J. F., \& Acocella, J. R. (1990). Psychology of adjustment and human relationships (third edition). New York: McGraw-Hill Inc.

Campo, R. A., Uchino, B. N., Vaughn, A., Reblin, M., Holt-Lundstand, J., \& Smith, T. W. (2009). The assassement of positivity and negativity in social networks: The reliability dan validity of the social relationships. Journal of Community Psychology, 37(4), 471-486. doi: $10.1002 /$ jcop. 20308

Chang, P.-C., \& Hsin, S. (2016). The examination of adolescents' motives, relational maintenance, and intimacy in their communications with parents. In The European Conference on Media, Communication \& Film. Diunduh dari http://25qt511nswfi49iayd31ch80-

wpengine.netdna-ssl.com/wpcontent/uploads/papers/euromedia201 6/EuroMedia2016_30455.pdf

Christensen, T. H. (2009). "Connected presence" in distributed family life. New Media \& Society, 11(3), 433-451. doi: $\underline{10.1177 / 1461444808101620}$

Claes, M., Perchec, C., Miranda, D., Benoit, A., Bariaud, F., Lanz, M., ... Lacourse, É. (2011). Adolescents' perceptions of parental practices: A cross-national comparison of Canada, France, and Italy. Journal of Adolescence, 34(2), 225238. doi: 10.1016/j.adolescence. $\underline{2010.05 .009}$

Clark, M. S., \& Mills, J. R. (2012). A theory of communal (and exchange) relationships. In P. A. M. Van Lange, A. W. Kruglanski, \& E. T. Higgins (Eds.), Handbook of theories of social psychology. London: SAGE Publications Ltd.

Coatsworth, J. D., Duncan, L. G., Greenberg, M. T., \& Nix, R. L. (2010). Changing parent's mindfulness, child management skills and relationships quaity with their youth: Results form a randomized pilot intervention trial. J. Child Fam. Stud., 19, 203-217. doi: 10.1007/s10826-009-9304-8

Cosgrove, A. (2016). There will be helicopter parents to pay. Retrieved July 20, 2017, from https://www.etown.edu/offices/ writing-wing/There Will Be Helicopter Parents to Pay.pdf

Coyne, S. M., Bushman, B. J., \& Nathanson, A. I. (2012). Media and the family: A note from the guest editors. Family Relations, 61, 359-362. doi: 10.1111/j.1741-3729.2012.00713.x 
De-Goede, I. H. A., Branje, S. J. T., \& Meeus, W. H. J. (2008). Developmental changes in adolescents ' perceptions of relationships with their parents. Journal Youth Adolescence, 75-88. doi: 10.1007/s10964-008-9286-7

Deutsch, M. (2012). A theory of cooperation-competition and beyond. In $\mathrm{M}$. Van Lange, P. A, A. W. Kruglanski, \& E. T. Higgins (Eds.), Handbook of theories of social psychology. London: SAGE Publications Ltd.

Drake, A. S. (2013). Examining the relevance of parent-adolescent relationships in the romantic relationship quality of young adults. Dissertation. Kansas State University.

Fanti, K. A., Henrich, C. C., Brookmeyer, K. A., \& Kuperminc, G. P. (2008). Toward a transactional model of parent-adolescent relationship quality and adolescent psychological adjustment. Journal of Early Adolescence Volume, 28(2), 252-276. doi: $\underline{10.1177 /}$ $\underline{0272431607312766}$

Feldman, R. S. (2009). Development across the life span (Fifth Edition). New Jersey: Pearson Prentice Hall.

Fiske, A. P. (2004). Relational model theory. Retrieved February 20, 2015, from http://www.comm.umn.edu

Fuligni, A. J., \& Eccles, J. S. (1993). Perceived parent-child relationships and early adolescents ' orientation toward peers. Developmental Psychology, 29(4), 622-632. doi: 10.1037/0012$\underline{1649.29 .4 .622}$

Fullwood, C. (2015). The role of personality in online self-presentation. In A. Attril (Ed.), Cyberpsychology. Hampsire: Oxford University Press.

Gillovich, T., Keltner, D., \& Nisbett, R. E. (2011). Social psychology (Second Edition). New York: W. W. Norton \&
Company.

Gouws, E., Kruger, N., \& Burger, S. (2008). The adolescent. Johannesburg: Heinemann Publishers Ltd.

Hall, J. A., Coats, E. J., \& LeBeau, L. S. (2005). Nonverbal behavior and the vertical dimension of social relation: A meta-analysis. Psychological Bulletin, 131(6), 898-924. doi: 10.1037/0033$\underline{2909.131 .6 .898}$

Hertlein, K. M. (2012). Digital dwelling: Technology in couple and family relationships. Family Relations, 61, 374$387 . \quad$ doi: $10.1111 / j .1741-$ 3729.2012.00702.x

Higgins, J. M. (1982). Human relations concept and skills. New York: Random House, Inc.

Hughes, E. K., \& Gullone, E. (2010). Reciprocal relationships between parent and adolescent internalizing symptoms. Journal of Family Psychology, 24(2), 115-124. doi: $\underline{10.1037 / \mathrm{a} 0018788}$

Jennings, N., \& Wartella, E. (2004). Technology and the family. In A. L. Vangelisti (Ed.), Handbook of Family Communication. New Jersey: Lawrence Erlbaum Associates.

Kelley, H. H. (1983). Analyzing close relationships. In H. H. Kelley, E. Berscheid, A. Christensen, J. H. Harvey, T. L. Huston, \& G. Levinger (Eds.), Close relationships. New York: W. H. Freeman.

Koen, V. (2009). The parent-adolecent relationship and the emotional wellbeing of adolescents. Dissertation. South Africa: North-West Univeristy.

Kruglanski, A. W., \& Higgins, E. T. (2007). Social psychology: Handbook of basic principles(Second edition). New York: The Guilford Press. 


\section{QONITATIN, DKK}

Kuhar, M. (2010). Parental authority in adolescent-parents relationships. Druš. Istraž. Zagreb God., 6(110), 953-971.

Lingyun, L. U. O. (2010). Investigation and analysis of parent-child relationships in adolescence. Journal of Cambridge Studies, 5(2-3), 87-97. doi: 10.17863/CAM.1360

Liska, J. (1998). Ants to elephants: A comparative perspective on the meaning of relationship. In R. L. Conville \& L. E. Rogers (Eds.), The meaning of "relationship" in interpersonal communication. Westport: Praeger Publishers.

Liu, S.-H., Yin, M.-C., \& Huang, T.-H. (2013). Adolescents' interpersonal relationships with friends, parents, and teachers when using facebook for interaction. Creative Education, 4(5), 335-339. doi: 10.4236/ce.2013.45049

Manstead, A. S. R., \& Hewstone, M. (1996). The blackwell encyclopedia of social psychology. (A. S. R. Manstead \& M. Hewstone, Eds.). Oxford: Blackwell Publishers Ltd.

McGrath, S. (2012). The impact of new media technologies on social interaction in the household. Irlandia: National University of Ireland Maynooth.

Mcgue, M., Elkins, I., Walden, B., \& Iacono, W. G. (2005). Perceptions of the parent - adolescent relationship : A longitudinal investigation. Developmental Psychology, 41(6), 971984. doi: $\underline{\text { 10.1037/0012-1649.41.6.971 }}$

McKinney, C., \& Renk, K. (2011). A multivariate model of parent adolescent relationship variables in early adolescence. Child Psychiatry Hum Dev, 42, 442-462. doi: 10.1007/s10578-011-0228-3

Moawad, G. E. N. A., \& Ebrahem, G. G. S. (2016). The relationships between use of technology and parent-adolescents social relationship. Journal of Education and Practice, 7(14), 168-178.

Moore, K. A., Kinghorn, A., \& Bandy, T. (2011). Parental relationship quality and child outcames across subgroups. Child trends: Research brief. Retrieved from https://www.childtrends.org/wpcontent/uploads/2011/04/Child_Trends -2011_04_04_RB_MaritalHappiness. pdf

Obsuth, I., Moretti, M. M., Holland, R., Braber, K., \& Cross, S. (2006). Conduct disorders: New direction in promoting effective parenting and strengthening parent-adolescent relationships. J. Cdn. Acad. Child Adoles. Psychiatry, 15(1), 615.

Odendaal, W., Malcolm, C., Savahl, S., \& September, R. (2006). Adolescent, their parents, and information and communication technologies: Exploring adolescents' perceptions on how these technologies present in parentadolescent relationships. Indo-Pasific Journal of Phenomenology, 6(1), 1-8.

Padilla-Walker, L. M. (2006). “Peers I can monitor, it's media that really worries me!" Parental cognitions as predictor of proactive parental strategy choice. Journal of Adolescent Research, 21, 56-82. doi: $\underline{10.1177 / 0743558405282723}$

Padilla-Walker, L. M., Coyne, S. M., \& Fraser, A. M. (2012). Getting a higgspeed family connection: Associations between family media use and family connection. Family Relations, 61, 426$440 . \quad$ doi: $\quad$ 10.1111/j.17413729.2012.00710.x

Pamungkas, H. W. (2014). Interaksi orang tua dengan anak dalam menghadapi teknologi komunikasi internet. Jurnal Tesis PMIS Untan, 1-17.

Papalia, D. E., Olds, S. W., \& Feldman, R. 
D. (2007). Human development (10th Edition). New York: McGraw-Hill.

Partini. (2017). Perubahan peranan perempuan: Peluang dan tantangan. In Naskah Pidato Pengukuran Jabatan Guru Besar (tidak diterbitkan). Yogyakarta: Fakultas Ilmu Sosial dan Ilmu Politik Universitas Gadjah Mada.

Peris, R., Gimeno, M. A., Pinazo, D., Ortet, G., Carrero, V., \& Sanchiz, M. (2002). Online chat rooms: virtual spaces of interaction for socially oriented people. CyberPsychology \& Behavior, $5(1), 43-51$.

Poduthase, H. (2012). Parent-adolescent relationship and juvenile deliquency in Kerala, India: A Qualitative Study. Dissertation. The Univeristy of Utah.

Prensky, M. (2010). H. sapiens digital: From digital immigrants and digital natives to digital wisdom. Italian Journal of Educational Technology, 18(2), 17-24. doi: 10.17471/2499-4324/277

Rajeev, M. M., \& Jobilal. (2015). Effects of social media on social relationships: A descriptive study on the impact of mobile phones among youth population. Journal of Social Sciences, 4(2), 11-16.

Reading, H. F. (1996). Dictionary of the social science. New Delhi: Mehra Offset Printers.

Reis, H. T., Collins, W. A., \& Berscheid, E. (2000). The relationship context of human behavior and development. Psychological Bulletin, 126(6), 844-872. doi: $\underline{10.1037 / / 0033-2909.126 .6 .844}$

Rudi, J. H., Walknerm, A., \& Dworkin, J. (2014). Adolescent-parent communication in a digital world: Differences by family communication patterns. Youth \& Society, 1-18. doi: $\underline{10.1177 / 0044118 X 14560334}$
Santrock, J. W. (2007). Remaja (jilid pertama). Jakarta: Penerbit Erlangga.

Sarwono, S. W. (2008). Psikologi remaja. Jakarta: Grafindo Persada.

Saxena, R., Srivastava, N., \& Naithani, R. (2011). Disagreements in parentadolescent relationship: A comparison in middle class families and lower class families. Stud Home Com Sci, 5(2), 99-104.

Setiono, K. (2011). Psikologi keluarga. Bandung: Penerbit P.T. Alumni.

Sharaiveska, I. (2012). Family and mental satisfication and the use of social network technologies. Dissertation. University of Illinois.

Shaw, M. E., \& Costanzo, P. R. (1985). Theories of social psychology(Second edition). Singapore: McGraw-Hill Book Co.

Smith, B. (2003). The use of communication strategies in computermediated ommunication. System, 31(1), 29-53.

Soenens, B., Vansteenkiste, M., Luyckx, K., \& Goossens, L. (2006). Parenting and adolescent problem behavior: An integrated model with adolescent selfdisclosure and perceived parental knowledge as intervening variables. Developmental Psychology, 42, 305-318. doi: $10.1037 / 0012-1649.42 .2 .305$

Stattin, H., \& Kerr, M. (2000). Parental monitoring: A reinterpretation. Child Development, 71, 1072-1085.

Steinberg, L. (2016). Adolescence (Eleventh edition). New York: McGraw-Hill.

Steinberg, L., \& Silk, J. S. (2002). Parenting adolescents. In M. H. Bornstein \& B. Webber (Eds.), Handbook of parenting. New Jersey: Lawrence Erlbaum Associates.

Subrahmanyam, K., \& Greenfield, P. 


\section{QONITATIN, DKK}

(2008). Communicating online: Adolescent relationships and the media. The Future of Children, 18(1), 127. doi: $10.1353 /$ foc. 0.0006

Subrahmanyam, K., \& Šmahel, D. (2011). Digital youth: The role of media in development. New York: Springer.

Susandijani. (2017). ReplyASAP, Solusi komunikasi yang jadi mimpi buruk para remaja. Retrieved 2 October 2017 from https://gaya.tempo.co/read/906147/rep lyasap-solusi-komunikasi-yang-jadimimpi-buruk-para-remaja

Taylor, S. E., Peplau, L. A., \& Sears, D. O. (1994). Social psychology (Eight Edition). New Jersey: Prentice Hall.

Walther, J. B. (2011). Theories of computermediated communication and interpersonal relations. In M. L. Knapp \& J. A. Daly (Eds.), The handbook of interpersonal communication. Thousand Oaks: Sage.

Wang, B., Stanton, B., Li, X., Cottrell, L., Deveaux, L., \& Kaljee, L. (2013). The influence of parental monitoring and parent - adolescent communication on Bahamian adolescent risk involve- ment: A three-year longitudinal examination. Social Science \& Medicine, 97, 161-169. doi: 10.1016/ j.socscimed.2013.08.013

Weisskirch, R. S. (2009). Parenting by cell phone: Parental monitoring of adolescents and family relations. J. Youth Adolescence, 38, 1123-1139. doi: $\underline{10.1007 / s 10964-008-9374-8}$

Widiastuti, N., \& Widjaja, T. (2004). Hubungan antara kualitas relasi ayah dengan harga diri remaja putra. Jurnal Psikologi, 2(1), 22-43.

Williams, A. (2003). Adolescents's relationships with parents. Journal of Language and Social Psychology, 13(1), 21-24. doi: $\underline{10.1177 / 0261927 X 02250056}$

Wish, M., Deutsch, M., \& Kaplan, S. J. (1976), Perceived dimensions of interpersonal relations, Journal of Personality and Social Psychology, 33(4), 409-420.

Yaacob, M. J. (2006). Parent-adolescent relationships and its association to adolescents' self-esteem. Malaysian Journal of Medical Sciences, 13(1), 21-24. 